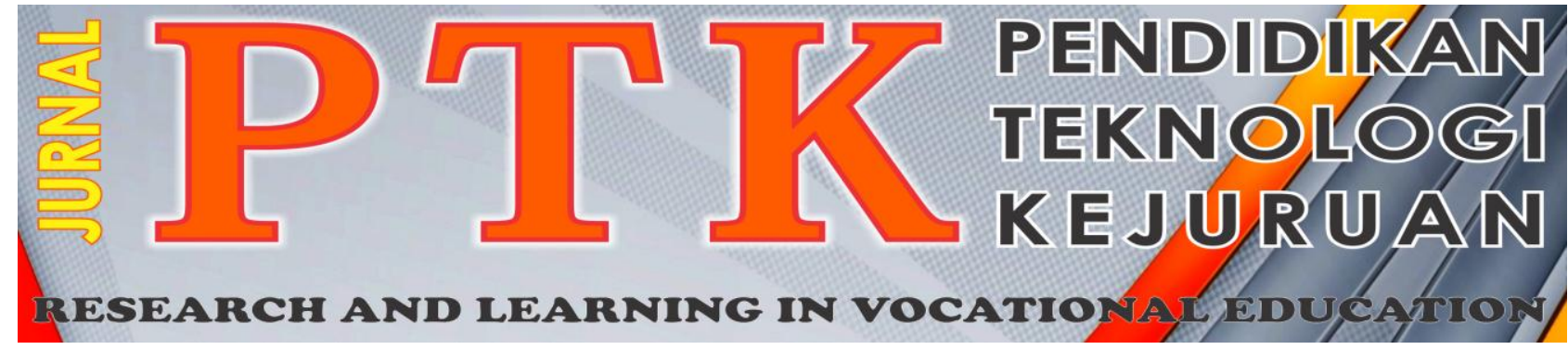

Vol. 1, No. 32018

\title{
PENGARUH MODEL PEMBELAJARAN PROBLEM SOLVING DAN MOTIVASI BERPRESTASI TERHADAP HASIL BELAJAR FISIKA SISWA SMK NEGERI 1 LAHAT
}

\author{
Tania Helvetia $^{1 *}$, Nizwardi Jalinus ${ }^{2}$ dan Refdinal ${ }^{3}$ \\ ${ }^{1}$ SMK Negeri 1 Lahat \\ ${ }^{23}$ Universitas Negeri Padang \\ *Corresponding author, e-mail: taniamulyono@gmail.com
}

\begin{abstract}
Abstrak - Penelitian ini berawal dari masalah banyaknya mahasiswa yang memperoleh nilai rendah pada mata pelajaran fisika. Tujuan penelitian ini adalah untuk mengetahui pengaruh metode pembelajaran dan motivasi berprestasi terhadap hasil belajar pada mata pelajaran fisika pada siswa SMK N 1 Lahat. Jenis penelitian ini adalah quasi eksperimen menggunakan desain faktorial $2 \times 2$, yakni dengan memperhatikan kemungkinan adanya variabel moderator yang mempengaruhi penelitian (independent variable) terhadap hasil (dependent variable). Populasi dalam penelitian ini adalah siswa kelas $\mathrm{X}$ yang berjumlah 587 orang. Sampel dalam penelitian ini adalah siswa kelas X TSM 1 untuk kelas eksperimen dan X TKR 1 untuk kelas kontrol dengan pertimbangan kelas tersebut memiliki tingkat kemampuan sama. Kelas X TSM 1 diberikan metode pembelajaran problem solving sedangkan kelas X TKR 1 diberikan metode pembelajaran konvensional. Teknik yang digunakan untuk menganalisis data hasil penelitian dengan menggunakan teknik anova dua jalur. Hasil penelitian ini membuktikan bahwa: a) rata-rata hasil belajar siswa yang diajarkan dengan metode problem solving, lebih tinggi dibandingkan dengan rata-rata hasil belajar siswa yang diajarkan dengan menggunakan metode pembelajaran konvensional, b). Rata-rata hasil belajar mata pelajaran fisika memiliki motivasi berprestasi lebih tinggi dibandingkan dengan rata - rata hasil belajar siswa memiliki motivasi rendah, c) terdapat interaksi antara metode pembelajaran dan motivasi berprestasi dalam mempengaruhi hasil belajar siswa di dalam mata pelajaran fisika.
\end{abstract}

Kata Kunci : Hasil Belajar, Metode Pembelajaran, Problem solving, Motivasi, fisika

Abstract-This research originated from a problem, namely, students who get low scores on physics subjects. The purpose of this study was to determine learning methods and achievement motivation on learning outcomes in physics subjects in students of SMK $N 1$ Lahat. This type of research is quasi-experimental using a $2 \times 2$ factorial design, namely by using a moderator variable that influences research (independent variables) to the results (dependent variable). The population in this study were X-class students who were 587 people. The sample in this study were students of class X TSM 1 for the experimental class and X TKR 1 for the control class with special classes that had the same ability level. Class X TSM 1 is used as a problem solving method while class X TKR 1 uses conventional learning methods. The technique used to analyze research data using a two-way ANOVA technique. The results of this study prove that: a) The average student learning outcomes used with problem solving are higher than the average learning outcomes of students who use conventional learning methods, b). The average learning outcomes of mathematics subjects have a higher achievement motivation compared to the average student learning outcomes have low motivation, c) there is an interaction between learning methods and motivation in learning.

Keywords: Learning Outcomes, Learning Methods, Problem solving, Motivation, physics

\section{Pendahuluan}

Sekolah Menengah Kejuruan (disingkat SMK) adalah salah satu bentuk satuan pendidikan formal yang menyelenggarakan pendidikan kejuruan pada jenjang pendidikan menengah sebagai lanjutan dari tingkat dibawahnya. SMK sering juga disebut STM (Sekolah Teknik Menengah) [1][2].

Mata pelajaran yang diberikan di sekolah menengah kejuruan (SMK) terbagi dalam tiga 
kelompok. Kelompok pertama termasuk dalam program produktif yaitu mata pelajaran dasar kejuruan (keteknikan) yang menjadi program utama sekolah kejuruan. Kelompok kedua termasuk dalam program adaptif yaitu mata pelajaran dasar yang mendukung program produktif dan termasuk didalamnya adalah mata pelajaran fisika. Sedangkan kelompok ketiga termasuk dalam program normatif yaitu mata pelajaran dasar umum [3][4]

Mata pelajaran fisika di SMK adalah sekumpulan bahan kajian atau materi pembelajaran tentang materi dan energi serta interaksinya sebagai pengetahuan dasar penunjang kejuruan, pengetahuan dasar pengembangan ilmu pengetahuan dan teknologi [5]. Sedangkan materi pembelajaran fisika berfungsi sebagai: pendukung berbagai program produktif, pendukung perkembangan ilmu pengetahuan dan teknologi, serta pendukung pengembangan sikap ilmiah dan profesional. Di samping itu pembelajaran fisika bertujuan agar siswa dapat: memahami konsep-konsep dasar fisika, menerapkan konsep-konsep dasar fisika dalam pekerjaan di dunia kerja dan kehidupan sehari-hari, serta memiliki wawasan intelektual dan bersikap ilmiah

Mata pelajaran fisika di SMK termasuk dalam program adaptif yaitu termasuk dalam mata pelajaran yang menunjang/mendukung program produktif. Pembahasan materi dari program adaptif harus diupayakan berkait erat dengan materi dari program produktif. Sementara itu materi program produktif harus selaras dengan dunia industri [6][7]. Materi yang dipelajari oleh siswa harus merupakan masalah nyata yang akan dijumpainya kelak ketika sudah lulus dan terjun dalam dunia industri. Oleh karena pembahasan konsep-konsep dalam mata pelajaran fisika harus selaras dengan mata pelajaran program produktif (bidang teknik), salah satu upaya yang dapat dilakukan adalah dengan memasukkan pembahasan penerapan konsep-konsep dasar fisika dalam dunia industri.

Mata pelajaran fisika mempersiapkan peserta didik agar dapat mengembangkan program keahliannya pada tingkat pendidikan yang lebih tinggi. Penguasaan mata pelajaran fisikamemudahkan peserta didik menganalisis proses-proses yang berkaitan dengan dasar-dasar kinerja peralatan dan piranti yang difungsikan untuk mendukung pembentukan kompetensi program keahlian

Pelajaran fisika adalah pelajaran yang mengajarkan berbagai pengetahuan yang dapat mengembangkan daya nalar, analisa, sehingga hampir semua persoalan yang berkaitan dengan alam dapat dimengerti. Untuk dapat mengerti fisika secara luas, maka harus dimulai dengan kemampuan pemahaman konsep dasar yang ada pada pelajaran fisika. Berhasil atau tidaknya seorang siswa dalam memahami tentang pelajaran fisika sangat ditentukan oleh pemahaman konsep.

Pada pelajaran fisika siswa bertemu dengan hitungan sebagaimana pada pelajaran matematika selain itu siswa juga menemukan banyak rumus yang harus mereka hafalkan ketika mengerjakan soal. Diperlukan adanya pemahaman konsep yang baik hingga siswa dapat mengerjakan soal-soal pada pelajaran fisika.

Namun banyak orang yang memandang fisika sebagai bidang studi yang paling menakutkan bagi siswa. Meskipun demikian, semua orang harus mempelajarinya karena setiap manusia akan menggunakan fisika di dalam kehidupanya, karena setiap ilmu dan pelajaran akan berhubungan dengan fisika. Selain itu fisika juga merupakan sarana untuk memecahkan masalah dalam kehidupan sehari-hari.

Menyadari akan pentingnya peranan dan kontribusi fisika dalam kehidupan manusia, seharusnya pelajaran fisika diusahakan menjadi pelajaran yang menarik serta menimbulkan kemauan dan semangat siswa dalam mempelajarinya. Namun kenyataan menunjukkan bahwa pelajaran fisika dianggap sebagai mata pelajaran yang tidak menarik, abstrak, sarat rumus matematika dan sulit dimengerti. Hal ini tentu mengakibatkan hasil belajar fisika siswa lebih rendah dibandingkan mata pelajaran lain.

Oleh karna itu salah satu cara untuk meningkatkan hasil belajar siswa adalah dengan meningkatkan sumber daya manusia melalui proses belajar mengajar [8]. Fisika adalah mata pelajaran yang banyak menuntut intelektualitas yang relatif tinggi sehingga sebagian besar siswa mengalami kesulitan mempelajarinya [9].

Belajar adalah perubahan tingkah laku atau penampilan, dengan serangkaian kegiatan misalnya dengan membaca, mengamati, mendengarkan, mendengarkan, meniru dan lain sebagai nya. Pembelajaran mengandung makna adanya kegiatan belajar dan mengajar, dimana pihak yang mengajar adalah guru yang akan mengajarkan materi atau sebagai fasilitator dalam upaya pengembangan pengetahuan, sikap, dan keterampilan siswa yang merupakan sasaran pembelajaran.

Agar proses belajar mengajar dapat berlangsung dengan baik maka salah satu cara yang harus dilakukan guru adalah merencanakan pengajaran tersebut terlebih dahulu. Guru harus bisa memilih model yang tepat sesuai dengan kondisi kelas dan materi. Pemilihan model yang tepat akan memberikan hasil belajar yang baik. Jadi metode pembelajaran merupakan salah satu penentu keberhasilan suatu proses pembelajaran. 
Berdasarkan hasil observasi dan tanya jawab terhadap guru-guru serta para siswa di SMK N 1 Lahat diperoleh informasi bahwa penggunan metode dalam pembelajaran fisika belum bervariasi. Hal ini menyebabkan kurangnya motivasi berprestasi siswa terhadap mata pelajaran fisika, sehingga kebanyakan siswa menganggap pembelajaran fisika sulit.

Pandapat ini juga didukung oleh Faizi yang mengemukakan bahwa Fisika termasuk salah satu pelajaran yang keberadaannya kerap menjadi menakutkan bagi sebagian besar siswa. Keadaan yang demikian ini lebih diperparah lagi dengan penggunaan model pembelajaran Fisika yang tidak tepat. Mengapa siswa tidak mempunyai keterampilan-keterampilan yang diperlukan dalam pemecahan masalah karena siswa tidak mampu menerapkan pengetahuan yang telah dipelajari untuk memecahkan soal-soal Fisika yang dihadapi [10].

Dengan banyaknya pengembangan dan penelitian mengenai metode belajar maupun para ahli, sudah sepatutnya guru memahami berbagai model belajar dan menerapkannya dalam proses belajar mengajar di sekolah. Model pembelajaran tersebut dapat dikembangkan dalam suatu model pembelajaran yang didukung dengan model belajar yang baik sehingga mampu memotivasi siswa dan menciptakan suatu proses belajar yang dapat mengeksplorasi wawasan pengetahuan siswa dan dapat mengembangkan makna sehingga akan memberikan kesan yang mendalam terhadap apa yang telah dipelajarinya.

Dari observasi yang telah dilakukan siswa mencapai nilai diatas ketuntasan kriteria minimum tidak lebih dari $40 \%$ dan selebihnya sebanyak $60 \%$ lebih siswa belum mampu mencapai nilai diatas KKM. Penyebab kualitas pendidikan rendah khususnya pada pembelajaran fisika tidak terlepas dari kemampuan guru memilih model ataupun metode pembelajaran yang tepat. Selain itu, metode pembelajaran yang dilakukan guru kurang menciptakan komunikasi dan interaksi yang baik antara guru dengan siswa dan antara siswa dengan siswa dan antara siswa dengan lingkungannya menyebabkan proses belajar mengajar yang monoton.

Pada umumnya di sekolah-sekolah sering dijumpai siswa-siswi yang tidak tertarik belajar fisika. Hal ini terjadi karena pada kenyataannya dalam pelaksanaan pembelajaran fisika setiap kegiatan didalam kelas didominasi oleh guru. Pada umumnya metode pembelajaran yang diterapkan disekolah masih konvensional yaitu masih berpusat pada guru. Empat dari 6 orang guru SMK Negeri 1 Lahat masih beranggapan bahwa metode pembelajaran konvensional masih sesuai dan paling baik, padahal metode mengajar konvensional yang digunakan guru memperkecil kemungkinan siswa untuk terlibat aktif dalam bertanya, menjawab pertanyaan, mengeluarkan pendapat dan berdiskusi dengan teman lain. Sehingga Jika guru memberi pertanyaan sangat jarang siswa yang mau menjawab, bahkan tidak jarang aktivitas yang dilakukan terkesan dipaksakan misalnya siswa baru menjawab pertanyaan gurunya bila sudah mendapat perintah atau ditunjuk oleh guru. Ketika menjawab, siswa hanya berusaha menjawab soal dengan cara meniru cara guru menyelesaikan soal atau dengan contoh yang ada.

Salah satu komponen yang diperkirakan juga mempengaruhi prestasi belajar fisika adalah motivasi berpestasi siswa terhadap fisika. Motivasi berprestasi merupakan faktor pendorong untuk menentukan keberhasilan dalam belajar dan untuk meraih atau mencapai sesuatu yang diinginkannya agar meraih kesuksesan. hal yang penting bagi proses belajar mengajar. Belajar yang dilandasi dengan motivasi berprestasi akan menimbulkan motivasi tersendiri bagi siswa untuk belajar lebih giat dalam proses pembelajaran sehingga siswa lebih cepat memahami materi belajar. Ketika proses belajar mengajar berlangsung beberapa siswa tidak bersungguh-sungguh mengikuti pelajaran, sering bercakap-cakap, bercanda sambil belajar, masih izin keluar kelas dalam waktu yang lama, peserta didik yang duduk dibelakang biasanya cenderung memiliki konsentrasi yang rendah terhadap pelajaran, jika diberi tugas atau latihan mereka tidak percaya diri sehingga cenderung mencontek atau mengandalkan jawaban temannya. Dari permasalahan tersebut tentu saja jelas membuktikan bahwa para siswa tidak tertarik atau berminat mengikuti pelajaran fisika. Hal tersebut tentu saja berimbas pada hasil belajar siswa.

Berangkat dari kondisi dan beberapa masalah pembelajaran yang ada, diperlukan adanya upaya guru secara terus menerus dan sistematis untuk meningkatkan efektivitas pembelajaran mata pelajaran fisika di SMK Negeri 1 Lahat. Salah satu upaya yang dapat dilakukan adalah perlu diterapkannya model pembelajaran yang memberikan kesempatan yang luas pada siswa dalam proses pembelajaran. Salah satu model pembelajaran yang memberikan kesempatan kepada siswa yang langsung mengarah kepada pemecahan masalah yang dihadapi oleh siswa dalam mengikuti kegiatan pembelajaran adalah model problem solving. Model Problem Solving dalam proses pembelajaran memberikan kesempatan kepada siswa untuk belajar optimal, hal ini mengandung pengertian bahwa perlakuan yang diterapkan dalam proses belajar mengajar menggunakan daya pikir dan kreativitas berpikir secara efektif dan efisien 
guna mencapai tujuan pembelajaran. Pendekatan ketrampilan proses dengan menggunakan model Problem Solving diterapkan dengan memandang siswa beserta kegiatannya sebagai manusia utuh, diterjemahkan dalam kegiatan belajar mengajar yang memperhatikan perkembangan pengetahuan, nilai hidup serta sikap, perasaan serta ketrampilan sebagai suatu kesatuan yang utuh baik sebagai tujuan maupun sekaligus bentuk pelatihannya, yang akhirnya semua kegiatan dan hasilnya tersebut diwujudkan dalam bentuk kreativitas.

Model Problem Solving adalah suatu proses mental dan intelektual dalam menemukan masalah dan memecahkan berdasarkan data dan informasi yang akurat, sehingga dapat diambil kesimpulan yang tepat dan cermat [11]. Problem solving yaitu suatu pendekatan dengan cara problem identifikation untuk ketahap syntesis kemudian dianalisis yaitu pemilahan seluruh masalah sehingga mencapai tahap application selajutnya komprehension untuk mendapatkan solution dalam penyelesaian masalah tersebutsalah satu alternatif model pembelajaran yang diterapkan dalam proses pembelajaran mata pelajaran matematika. Model Problem Solving lebih menekankan pada kegiatan-kegiatan yang berpusat dalam pemecahan masalah maupun pengembangan kreativitas belajar siswa. Penerapan model Problem Solving dapat membantu guru dalam menyampaikan materi pembelajaran dengan menciptakan kondisi pembelajaran yang kondusif dalam menumbuhkan motivasi berprestasi siswa untuk belajar lebih dalam, akan mendorong rasa ingin tahu siswa lebih lanjut dan mendorong siswa untuk berfikir kritis. Berkembangnya rasa ingin tahu, berfikir kritis, analisis dan rasa kepuasan dalam belajar siswa kiranya dapat digunakan dalam pengelolaan proses pembelajaran agar mencapai hasil belajar yang optimal.

Pemecahan masalah merupakan bagian dari kurikulum matematika yang sangat penting karena dalam proses pembelajaran maupun penyelesaiannya, siswa dimungkinkan untuk memperoleh pengalaman menggunakan pengetahuan serta keterampilan yang sudah dimiliki. Siswa membutuhkan keterampilan dan penguasaan terhadap materi ataupun konsep yang digunakan dalam kegiatan pemecahan masalah,. Erman Suherman menyatakan bahwa pemecahan masalah menunjuk pada proses pemanfaatan skemata atau apa-apa yang telah ada dalam pikiran pebelajar untuk menguasai situasi baru [12]. Dengan cara itu dalam diri pebelajar terbentuk skemata baru yang secara kualitatif lebih kompleks atau lebih maju.

Problem solving yaitu suatu pendekatan dengan cara problem identifikation untuk ketahap syntesis kemudian dianalisis yaitu pemilahan seluruh masalah sehingga mencapai tahap application selajutnya komprehension untuk mendapatkan solution dalam penyelesaian masalah tersebut. Langkah-langkah Problem Solving yaitu: (1) Memberikan permasalahan kepada siswa dimana permasalahan tersebut berhubungan dengan kehidupan sehari-hari; (2) Guru mengorganisasikan siswa dalam beberapa kelompok; (3) Guru mengamati cara siswa selama proses menentukan pemecahan masalah yang diajukan. Guru memberikan arahan secukupnya jika siswa mengalami kesuliatan dalam menentukan pemecahan masalah; (4) Guru meminta siswa untuk menyajikan laporan hasil pemecahan masalah yang diajukan dan mempresentasikan di dalam kelas; (5) Guru mengajak siswa untuk mengevaluasi proses pemecahan masalah yang diajukan [11].

Berdasarkan uraian di atas tampak jelas bahwa pembelajaran dengan model Problem Based Learning dimulai dengan adanya masalah, kemudian siswa memperdalam pengetahuannya tentang apa yang mereka ketahui untuk memecahkan masalah tersebut. Dalam pembelajaran ini masalah-masalah yang dijadikan sebagai fokus pembelajaran dapat diselesaikan siswa melalui kerja kelompok sehingga dapat memberi pengalaman-pengalaman belajar yang beragam pada siswa seperti kerjasama dan interaksi dalam kelompok, disamping pengalaman belajar yang berhubungan dengan pemecahan masalah seperti membuat hipotesis, merancang percobaan, melakukan penyelidikan, mengumpulkan data, mengintepretasi data, membuat kesimpulan, mempresentasikan, berdiskusi dan membuat laporan.

\section{Metode}

Metode yang digunakan dalam penelitian ini adalah metode penelitian quasi eksperimen bertujuan untuk meneliti hubungan sebab dan akibat dengan cara memberikan satu atau lebih kondisi perlakuan kepada satu atau lebih kelompok eksperimental, dan membandingkan hasilnya terhadap satu atau lebih kelompok kontrol yang tidak menerima perlakuan [13]. Di dalam penelitian ini terdapat 2 kelompok, kelompok eksperimen dan kelompok kontrol yang ditentukan berdasarkan teknik cluster random sampling. Kedua kelompok diasumsikan sama dan hanya berbeda dalam penerapan metode pembelajarannya. Kelompok eksperimen merupakan kelompok yang mendapat perlakuan, dengan menggunakan model pembelajaran Problem solving, sedangkan kelompok kontrol diajar menggunakan metode pembelajaran konvensional. Sementara itu kelompok kontrol dalam penelitian ini adalah sebagai pembanding untuk kelompok eksperimen. 
Penelitian ini menggunakan desain faktorial 2 $\times 2$, yakni dengan memperhatikan kemungkinan adanya variabel moderator yaitu motivasi belajar yang mempengaruhi metode belajar terhadap hasil (variable dependen) [14]. Variabel bebas dalam penelitian ini adalah model pembelajaran problem solving dan motivasi berprestasi. Kemudian variabel terikat adalah hasil belajar. Di sini akan dibandingkan siswa dengan motivasi tinggi pada pada kelas eksperimen dengan motivasi tinggi siswa pada kelas kontrol dan motivasi rendah siswa pada kelas eksperimen dengan motivasi rendah siswa pada kelas kontrol.

Populasi penelitian ini dalah siswa kelas $\mathrm{X}$ SMK N 1 Lahat Tahun Pelajaran 2017/2018, Populasi dalam penelitian ini sebanyak 587 siswa. Yang terdiri dari Teknik komputer \& Informasi, Teknik otomotif, Teknik Geologi Pertambangan, Teknik udio Video, Teknik Bangunan, Teknik Mesin, Teknik Instalasi tenaga Listrik.

Metode pengambilan sampel yang digunakan adalah teknik cluster random sampling. "Teknik cluster random sampling adalah teknik pengambilan sampel dengan melakukan randomisasi terhadap kelompok, bukan subyek sebagai individual". [15]. Setiap anggota yang berada dalam cluster yang terambil secara acak merupakan sampel yang diperlukan [16]. Langkah pertama, dilakukan pengundian terhadap 17 kelas program keahlian di SMK N 1 Lahat dan muncullah kelas X Teknik Sepeda Motor dan Teknik Kendaraan Ringan sebagai sampel. Langkah kedua, dari 2 program studi tersebut diundi untuk menentukan kelas eksperimen dan kelas kontrol. Hasil pengundian di peroleh kelas X TSM 1 sebagai kelas eksperimen dan kelas X TKR 1 sebagai kelas control.

Penelitian ini menggunakan dua jenis instrumen, yaitu: a) Instrumen angket adalah instrumen yang digunakan untuk mengumpulkan data yang berhubungan dengan motivasi berprestasi siswa dan b) Instrumen Tes. Tes yang diberikan sesuai dengan materi kompetensi selama perlakuan berlangsung. Teknik Analisis Data yang digunakan menggunakan anova dua jalur karena dengan taraf signifikansi $(\alpha=5 \%)$.

\section{HASIL DAN PEMBAHASAN}

\section{Hasil belajar Fisika Siswa yang Diajar dengan Model Pembelajaran Problem Solving Lebih Tinggi dari Siswa yang Diajarkan Model Pembelajaran Konvensional}

Hasil belajar rata-rata siswa yang diajarkan dengan menggunakan model pembelajaran Problem Solving dan yang diajar dengan menggunakan model konvensional dapat dilihat pada Tabel 1 yaitu:
Tabel 1. Rata-rata Hasil Belajar Siswa dengan Model Pembelajaran Problem Solving dan Model Konvensional

\begin{tabular}{lc}
\hline \multicolumn{1}{c}{ Model } & Rata-rata hasil belajar \\
\hline Model pembelajaran & 76,3 \\
Problem Solving & \\
Model pembelajaran & 69,5 \\
konvensional & \\
\hline
\end{tabular}

Temuan ini membuktikan bahwa pembelajaran dengan menggunakan model pembelajaran Problem Solving lebih unggul dalam meningkatkan hasil belajar siswa dibandingkan dengan menggunakan model pembelajaran konvensional.

Pada kelas kontrol yang dalam pembelajaran menggunakan metode konvensional, yaitu ceramah, hasil belajar mereka masih rendah jika dibandingkan dengan dengan hasil belajar kelas eksperimen yang menggunakan model pembelajaran Problem Solving. Pembelajaran di kelas kontrol menggunakan metode ceramah, sehingga siswa tidak aktif dan merasa kurang bersemangat dalam pembelajaran. Ini dapat dilihat dari rata-rata hasil belajar siswa yang diajarkan dengan menggunakan model pembelajaran Problem Solving yang dibandingkan dengan hasil belajar siswa yang diajarkankan dengan menggunakan metode pembelajaran konvensional.

Selama proses pembelajaran pada kelas kontrol, kadang kala siswa merasa bosan dan mengantuk mendengar guru berceramah dan memberikan penjelasan, sehingga pada saat mereka mengerjakan latihan dan tugas yang diberikan, mereka kebingungan bagaimana cara menyelesaikannya dan mencari jalan pintas dengan menyalin punya teman. Untuk beberapa siswa guru bisa memberikan penjelasan ulang, tetapi hal itu tidak dapat dilakukan untuk keseluruhan siswa, karena terkendala dengan jam pelaran yang tersedia hanya 2 jam pelajaran, sedangkan materi yang akan dipelajari sangat padat. Mereka kurang aktif dalam belajar dan terbiasa menerima apa yang disampaikan oleh guru. Hanya sebagian kecil dari siswa pada kelas kontrol yang memiliki keinginan untuk menyelesaikan soal latihan, kebanyakan mereka lebih senang menyontek tugas temannya dari pada mencari sendiri.

\section{Hasil Belajar Fisika Siswa yang Memiliki Motivasi BerprestasiTinggi Lebih Tinggi Dibanding Siswa yang Memiliki Motivasi Berprestasi Rendah}

Temuan ini menunjukkan bahwa motivasi berprestasi siswa sangat berpengaruh pada cara pembelajaran baik pembelajaran yang menggunakan model pembelajaran Problem Solving maupun yang 
menggunakan model pembelajaran konvensional. Siswa akan memperoleh hasil belajar lebih tinggi jika mereka memiliki motivasi berprestasi yang tinggi. Sebaliknya siswa yang memiliki motivasi berprestasi rendah akan memperoleh hasil belajar yang lebih rendah daripada siswa yang memiliki motivasi berprestasi tinggi.

Tabel 2. Rata-rata Motivasi Beprestasi Siswa dengan Model Pembelajaran Problem Solving dan Model Konvensional

\begin{tabular}{lc}
\multicolumn{3}{c}{ Model } & $\begin{array}{l}\text { Rata-rata Motivasi } \\
\text { Beprestasi }\end{array}$ \\
\hline $\begin{array}{l}\text { Model pembelajaran } \\
\text { Problem }\end{array}$ & 51,85 \\
Modving & \\
konvensional pembelajaran & 49,64 \\
\hline
\end{tabular}

\footnotetext{
Pembelajaran Fisika sangat erat kaitannya dengan teori belajar konstruktivisme. "Konstruktivisme merupakan landasan berpikir (filosofi) pendekatan kontekstual, yaitu pengetahuan dibangun sedikit demi sedikit, yang hasilnya diperluas melalui konteks yang terbatas (sempit) dan tidak dengan tiba-tiba" [17]. Kaitan antara pembelajaran Fisika dengan teori konstruktivis tersebut, didasarkan oleh hakikat dari Fisika itu sendiri yang tidak terlepas dari kehidupan seharihari siswa. Sehingga, siswa senantiasa memiliki kontak langsung dengan beragam objek kajian Fisika. Pemahaman inilah yang menjadi dasar bahwa dalam mempelajari Fisika, siswa dipahami telah memiliki motivasi berprestasi. Sehingga proses belajar dalam Fisika memerlukan diketahuinya motivasi berprestasi siswa terkait materi ajar Fisika, yang nantinya dapat mendukung tercapainya hasil belajar yang sesuai dengan harapan.

Proses belajar Fisika yang pernah dialami oleh siswa pada jenjang pendidikan sebelumnya, ataupun pengalaman yang diperoleh siswa dalam kehidupan sehari-hari, menjadikan dasar bagi terbentuknya motivasi berprestasi siswa. Karena pada dasarnya, "Siswa adalah organisme yang unik yang berkembang sesuai dengan tahap perkembangannya. Perkembangan anak adalah perkembangan seluruh aspek kepribadiannya, akan tetapi tempo dan irama perkembangan masing-masing anak pada setiap aspek tidak selalu sama"[18]. Motivasi berprestasi siswa, tentu tidaklah sama antara satu siswa dengan siswa yang lain. Karena pada dasarnya, siswa memiliki karakteristik masing-masing. Oleh karena itu, dengan mengetahui motivasi berprestasi siswa, guru dapat lebih mempersiapkan darimaan memulai pelajaran dan metode apa yang harus digunakan.
}

\section{Terdapat Interaksi Model Pembelajaran dan Motivasi berprestasi terhadap Hasil Belajar}

Berdasarkan uji Anova pada hipotesis ketiga menunjukkan bahwa terdapat interaksi antara model pembelajaran dan motivasi berprestasi terhadap hasil belajar. Interaksi merupakan hubungan ketergantungan antara satu variabel terhadap taraf tertentu dari variabel lain.

Siswa dengan motivasi berprestasi tinggi yang diajar dengan menggunakan model pembelajaran Problem Solvingdapat meningkatkan hasil belajar dan begitu juga dengan siswa dengan motivasi berprestasi rendah, dapat meningkatkan hasil belajarnya menjadi lebih tinggi. Hal ini menunjukkan bahwa pembelajaran dengan menggunakan model pembelajaran Problem Solving cukup efektif dalam meningkatkan hasil belajar siswa.

Hal ini berarti masing-masing faktor (model pembelajaran atau motivasi berprestasi) berinteraksi mempengaruhi hasil belajar siswa. Kedua hal tersebut (model pembelajaran atau motivasi berprestasi) mempunyai posisi sendiri terhadap hasil belajar. Ada kalanya motivasi berprestasi siswa lebih menentukan hasil belajar, namun disisi lain ada kalanya model pembelajaran yang mempengaruhi hasil belajar siswa. Manfaat dari model pembelajaran Problem Solving ini baik digunakan untuk siswa yang memiliki motivasi berprestasi tinggi, maupun siswa yang memiliki motivasi berprestasi rendah.

Hal ini menjadi bukti bahwa model pembelajaran yang baik dan sesuai yang digunakan oleh guru sebagai ujung tombak dalam pembelajaran sangat mempengaruhi hasil belajar siswa. Motivasi berprestasi yang dimiliki oleh siswa menjadi pijakan awal guru dalam menerapkan model pembelajaran yang baik.

\section{KESIMPULAN}

Berdasarkan hasil analisis dan pembahasan data penelitian yang telah dilakukan oleh peneliti, dapat disimpulkan bahwa

1. Siswa yang melakukan pembelajaran dengan menggunakan model pembelajaran problem solving terbukti rata-rata hasil belajar Fisika lebih tinggi dari siswa yang melakukan pembelajaran dengan model konvensional. Artinya model pembelajaran problem solving memberikan pengaruh yang sangat penting dalam meningkatkan hasil belajar siswa.

2. Siswa yang memiliki motivasi berprestasi tinggi terbukti rata-rata hasil belajar Fisika lebih tinggi dari siswa yang memiliki motivasi berprestasi rendah. Artinya motivasi berprestasi siswa 
memberikan pengaruh yang sangat penting terhadap hasil belajar.

3. Terdapat interaksi antara model pembelajaran dengan motivasi berprestasisiswa dalam mempengaruhi hasil belajar siswa. Berarti masing-masing variabel mampu meningkatkan hasil belajar siswa baik memiliki motivasi berprestasi yang tinggi maupun rendah.

\section{DAftar Pustaka}

[1] R. E. Wulansari, D. Puyada, I. Wijaya, and K. Rukun, "EFFECTIVENESS OF INSTRUCTIONAL MEDIA BASED GAME ON MATHEMATICS AT VOCATIONAL HIGH SCHOOL," Int. J. Res. Sci. Manag., vol. 4, no. 12, pp. 125-128, 2017.

[2] R. Lapisa, I. Y. Basri, A. Arif, and H. D. Saputra, "PENINGKATAN KOMPETENSI SISWA MELALUI PELATIHAN AUTO CAD," vol. 17, no. 2, 2017.

[3] D. Pernanda, M. A. Zaus, R. E. Wulansari, and S. Islami, "Effectiveness of instructional media based on interactive cd learning on basic network at vocational high school: improving student cognitive ability," Int. Conf. Educ. Soc. Sci. Technol., no. January, pp. 440-444, 2018.

[4] S. Sukardi, D. Puyada, R. E. Wulansari, and D. T. P. Yanto, "The validity of interactive instructional media on electrical circuits at vocational high school and technology," in the 2nd INCOTEPD, 2017, vol. 2017, no. October, pp. 21-22.

[5] M. A. Zaus, R. E. Wulansari, S. Islami, and D. Pernanda, "Perancangan Media Pembelajaran Listrik Statis dan Dinamis Berbasis Android," vol. 1, no. 1, pp. 1-7, 2018.

[6] N. Jalinus, Syahril, and R. A. Nabawi, "Effectivity of The Cooperative-Project Based Learning ( CPjBL ) in Enhancing HOTS of Vocational Education Students," no. 1, pp. 83-86, 2018.
[7] M. A. Zaus, "Suatu Kajian Literatur MasalahMasalah yang Dihadapi dalam Mata Kuliah Jaringan Komputer," vol. 18, no. 1, pp. 1-8, 2018.

[8] S. Islami and S. Yondri, "PERBEDAAN HASIL BELAJAR SISWA DALAM PEMBELAJARAN KOOPERATIF TIPE JIGSAW DENGAN KONVENSIONAL," in National Conference of Applied Engineering, Business and Information Technology, Politeknik Negeri Padang, 2016.

[9] Mundilarto. Penilaian Hasil Belajar Fisika. Yogyakarta: Pusat Pengembangan Instruksional Sains, 2010.

[10] Faizi, Mastur. Ragam Metode Mengajarkan Eksakta pada Murid. Yogyakarta: Diva Press, 2013.

[11] Hamalik, Oemar. Proses Belajar Mengajar. Jakarta: Bumi Aksara, 2011.

[12] Erman Suherman, dkk. Strategi Pembelajaran Matematika Kontemporer. Bandung: UPI, 2003.

[13] Setyosari, Punaji. Metode Penelitian Penelitian dan Pengembangan. Jakarta: Kencana, 2010.

[14] Sugiyono. Metode Penelitian Kuantitatif, Kualitatif, dan R\&D. Bandung: Alfabeta, 2009.

[15] Syaifuddin Azwar. Realibilitas dan Validitas. Yogyakarta: Pustaka Pelajar, 2014.

[16] Sudjana, Nana. Penilaian Hasil Proses Belajar Mengajar. Bandung: Remaja Rosdakarya, 2011.

[17] Sagala, Syaiful. Konsep dan Makna Pembelajaran. Bandung: Alfabeta, 2010.

[18] Sanjaya, Wina. Strategi Pembelajaran Beorientasi Standar Pendidikan. Jakarta: Kencana Prenada Media, 2009. 